\title{
IS THERE ANY PLACE FOR YUGOSLAV MEMORIALS IN THE CURRENT SERBIAN TOURIST OFFER?
}

\author{
Jasna Micić, \\ Stefan Denda
}

Geographical Institute "Jovan Cvijić" SASA, Belgrade, Serbia

\begin{abstract}
:
Cultural tourism is a very important tourism segment, which has been recording constant growth. The core of cultural tourism is a willingness to become familiar with other nations, cultures, and customs. Visiting monuments and memorials are the most common way to learn about foreign history and art. The monuments built during the existence of the Social Federative Republic of Yugoslavia represent prominent heritage, but also unique artistic achievements in European architecture from XX century. Therefore, the aim of this paper is to evaluate the heritage from the mentioned period, to compare the current state with the "golden" Yugoslav period and to propose strategies for the future tourism development. During the Yugoslav period, these monuments and memorials had commemorative, educative, and propaganda purpose. The major memorials were visited yearly by millions of people, so they also became important tourist attractions. After the disintegration of SFR Yugoslavia, these monuments were forgotten and neglected due to new political order. They became an unwanted legacy unknown for the visitors out of the territory of the former state union. Observing the global tourism demand, these memorials could be valorized through several forms of tourist activities (thematic routes, dark tourism, events, etc.). Furthermore, the transnational cooperation with the former Yugoslav republics could enable creating regional tours, which would be recognizable at the international level.
\end{abstract}

Keywords:

socialist heritage, modern architecture, tourism valorization, SFRY

\section{INTRODUCTION}

Cultural tourism has a long tradition and its roots could be found in early pilgrimage and the aristocratic "grand tours" from XVI century. Historically observed, culture and tourism were preserved only for an elitist part of society, while in the XIX century many cultural products became available for the public audience. At the latter XX and the beginning of the XXI century, the changes in the tourism demand occurred and it accelerated the cultural tourism development. During the last few decades, cultural heritage and tourism are unbreakable unity in the world. Tourism has been an economic justification for the protection of cultural heritage (Timothy, 1997). The institutions responsible for the preservation of cultural heritage tend to increase tourist traffic because it helps in raising the funds that could be used
Correspondence:

Jasna Micić

e-mail:

j.micic@gi.sanu.ac.rs 
for the restoration and protection of the heritage (Jovičić, 2008). Several types of studies showed that cultural tourists are older, more educated, and richer compared to the other types of travelers (Kerstetter et al., 1998; Craine, 1999; Kemmerling Clack, 1999). These claims are confirmed by the OECD data for 2007, which showed that cultural tours made around $40 \%$ of total tourism traffic and it was estimated that cultural tourists had $30 \%$ higher expenditure than others (OECD, 2009).

Cultural tourists are motivated to get to know the foreign culture, local community, and its heritage, but some of them are highly motivated by culture, while others showed as accidental cultural tourists. Based on the centrality of the cultural tourism in the destination selection and the depth of the tourist experience, McKercher (2002) defined five types of the cultural tourists: the purposeful cultural tourist, the sightseeing cultural tourist, the casual cultural tourist, the incidental cultural tourist, and the serendipitous cultural tourist (McKercher and du Cros, 2003, p. 47). The first four types in the McKercher's classification make most of the cultural tourist, while the last one represents the anomaly and takes the small percentage in the total number of the cultural tourists. Furthermore, one of the reasons for the cultural tourism growth is a constant improvement of the cultural offer. Destinations must be innovative to maintain their uniqueness and position in the global tourism market.

Cultural tourism is a subform of the broader phenomenon of heritage tourism, but at the same time, it can be expressed in many forms of niche tourism. An important place in cultural tourists' motivation takes the motivation for visiting monuments from different epochs of human history. This is the most common way to become familiar with the foreign culture and history.

The origin and the dissolution of Yugoslavia intrigue the international audience, but the monuments and memorials from that period are practically unknown. They have a high artistic value and are significant for the European history of architecture of the XX century. The architecture in Yugoslavia was different from the other socialist countries because the Yugoslav architects had their own expressive and abstract language. This inspired Martino Stierli, the Chief Curator of Architecture and Design at the New York Museum of Modern Art to create the exhibition Toward a Concrete Utopia: Architecture in Yugoslavia, 1948-1980, which were opened in July 2018. The main idea of the exhibition was to present Yugoslav architecture to the global audience, especially USA citizens who are mostly unfamiliar with it. Besides, bearing in mind growing attention towards Yugoslav monuments and marking them as "UFO monuments" at social media, this exhibition should present the historical background of the monuments and their social impact (Savković, 2018). Despite their artistic, historic and educative value, they have not been assessed, included, and presented in the official tourist offer of Serbia.

\section{HISTORY OF YUGOSLAV MEMORIALS}

The memory of the World War II is crucial for the creation of the collective identity of European people, and therefore of Yugoslav people (Vajagić, 2017). In Southeastern Europe monument policy, as a strategy for creating collective memory was usually used. It facilitated the process of creating and preserving national identity. Furthermore, it helped to convey a desirable message to the public audience, to promote new ideas, to demonstrate power, to leave testimony to new generations, and to enable the promotion of the political ideas (Dragićević Šešić, 2011). After the War and the creation of the Social Federative Republic of Yugoslavia in 1945, the idea of building common Yugoslav identity arose. In establishing new ideology, the whole society participated in, so it was incorporated in the many spheres of life: art, science, education, literature, music, moves, etc.

The memorial architecture was of major importance in creating Yugoslav identity and corrected collective memory with the emphasis of the certain events from the past. The light motives in creating official history were: the common struggle against fascism with the emphasis on the national liberation struggle (NOB) of Partisans, and brotherhood and unity (Dizdarević and Hudović, 2012; Jauković, 2015). During the fifty-year period, around 22,000 monuments were built in Yugoslavia. They were created in the places of important battles, symbolizing the national struggle for the freedom; places of painful human tragedy, like concentration camps, places of mass shotguns and massacres (Djurić, 2015). In 1952 the Association of Fighters of the National Liberation War (SUBNOR) was established. The SUBNOR coordinated the building of the monuments, the symbolism, opening ceremonies, commemoratives, etc. (Vajagić, 2017; Jauković, 2015). 


\section{THE PHASES OF THE MEMORIAL CONSTRUCTION}

The Yugoslavia memorials were erected through several phases. The first phase started in 1945 and lasted until 1948 and conflict with the Communist Information Bureau. In this phase were dominant socialist realism and the ideas from the Soviet Union. The memorials built in this period glorified Red Army and the Soviet Union as allies in liberation. The monuments were smaller in size like obelisks with the socialist symbols (red star, sickle, and hammer), but also in some cases with the orthodox cross (e.g. Murska Sobota in Slovenia (1945), Ritopek in Serbia (1946), and Batina in Croatia (1947)) (Djurić, 2015). In contrast to the previous, the second phase (1948-1952) was marked by the celebration of the National Liberation Army of Yugoslavia and its importance in gaining freedom (e. g. Monument in Iriški Venac, 1952). These monuments were supposed to send a message to USSS that Red army did not help the liberation. Also, the memorials from the first phase were removed. In the third phase (1952-1961) the memorials were idolized the national liberation struggle (NOB). The construction style became freer and the geometric figures became the basic mean of expression. The next phase began with the first Conference of the Non-Aligned Movement held in Belgrade (1961) and it lasted until Tito's death and the beginning of the end of Yugoslavia (1980). The following years are known as "golden age of Yugoslav architecture". During these years, the emphasis was put on the building the places where people can get spiritual experience, but without the inclusion of the traditional religion. From this idea, the new style known as socialist aestheticism emerged. The Communist Party supported the modernism among the artists to show how they are free in their artistic expressions, which was not common for the socialist countries. The new memorials were dedicated to the fallen civilians and the Partisan struggles against fascism. The most prominent artists from this period were Bogdan Bogdanović, Vojin Bakić, Miodrag Živković, and Dušan Džamonja. Their sculptures were not anthropogenic; they got an abstract and metaphoric form with concrete as most used material that was supposed to symbolize strength and durability. The memorials were built in a big, open, natural environment (national parks, nature parks, hilltops, etc.), which helped in conveying a desirable message. This phase was characterized by the mass construction of memorials (e.g. Kadinjača, Kragujevac, Prilep, Banja Luka, Tjentište, etc.) (Putnik, 2016). After the "charismatic leader's" death, the last phase started. It was marked by the decrease of the construction of the monument. It lasted until 1991 and the final collapse of Yugoslavia (Vajagić, 2017).

\section{THE PURPOSE OF MEMORIALS DURING THE YUGOSLAV PERIOD}

Numerous monuments erected during the Communist era testify the necessity of establishing desirable ideology. Observing their structure and space where they were built, they can be considered as the temples of communist ideology. The memorial complexes are more like memorial parks, built in nature at the historically important places (e.g. battlefields, concentration camps, cemeteries, etc.). They were organized as ordinary parks with benches, but also, they had amphitheater, museum, and memorial rooms. Constructed as the places with a purpose to combine mourning and celebration, complexes were well-equipped with the facilities, such as trails, hotel accommodation, restaurants, youth centers, sports facilities, etc. (Djurić, 2015; Musa et al., 2015). These complexes represented the important places for the gathering of several generations as places of living history and places where all nations should be united (Prekić, 2015). The Communist party supported daily use of memorials, with obligatory annually commemorative ceremonies. Besides, the big emphasis was put on the opening ceremonies, which were in form of spectacles. The amphitheater in the memorials enabled holding propaganda opening speeches, which were an inevitable part of the ceremony. These speeches were held by some local politicians, but often by Tito himself. Their main purpose was a presentation of the state achievements and plans. Besides honoring the sacrifice of the ancestors and expressing gratitude for the gained freedom, these opening ceremonies were used for the glorification of the presence and the current political order. Furthermore, cultural and artistic content was an integral part of the ceremony. Additionally, the special emphasis was put on the youth as pillars of the future and prosperity. Opening ceremonies would gather thousands of people from all state republics, but not all visits were voluntary. Some were obligatory, such as pupils' and students' visits during excursions and school visits as a part of the Yugoslav educational program. With all these facilities, activities, appealing surroundings, these memorial complexes became tourist attractions. 
The prominent memorials annually visited between four and five million people, so they had to be treated as tourist attractions. The majority of visitors were pupils and students on their excursions or school visits, war veterans, families of the fallen victims, politicians, etc. (Musa et al., 2015).

\section{DISSONANT YUGOSLAV HERITAGE}

Monuments and memorials are usually built to commemorate or preserve the memory of the certain event and to convey a message from the past to future generations. They do not have only one function: it can be grief place for the family members, a museum for the visitors, a place of torture for a survived camp inmate, or a place of collective memory for the state (Vajagić, 2017). Besides, it is certain that monuments have a different value in various political orders. Through time they can evolve from the symbols that bind to the symbols that divide. The major social and political changes are usually followed by the reinterpretation of the monuments' narrative and symbolism. The explanation for this situation can be found in the practice that during the rule of one political order, the so-called "elite" manages the construction of the monument, which is in accordance to their beliefs, leaving others indifferent or angry (Begić and Mraović, 2014). After the collapse of the regime, there are few possible scenarios addressing memorials from the past. It could be destruction and removal, neglect or heritage conservation (Dragićević Šešić, 2011). Observing memorials from the Yugoslav period, it could be concluded that they are mostly neglected and forgotten during the last three decades, but some of them were also destroyed and removed.

The fall of Yugoslavia had started with Tito's death in 1980 because he left the state union burden with problems (social, economic, and political). Officially the breakdown started after the multiparty elections in 1990. In 1991 the state republics, Slovenia and Croatia declared independence from SFR Yugoslavia, followed by Bosnia and Hercegovina (1992). These actions led to war in all three countries with big human and material tragedies (Begić and Mraović, 2014). With the collapse of Yugoslavia and the downfall of the idea of "brotherhood and unity", the reconstruction of the national identities of former state Republics has started. A new national order demanded history rewriting and thereby different relation towards memorials from the previous period. The monuments that symbolized state pride and victory over fascism now became anti-monuments and reminders of the past that should be deleted (Djurić, 2015). The monuments and memorials also became "dissonant heritage", which should be forgotten (Dragićević Šešić, 2011).

Almost three-decade after the breakup of Yugoslavia and civil wars, attitudes towards socialist's past differ at the regional level. Most of the monuments have been abandoned, silent, forgotten, many were destroyed during the civil war, and some of them were removed (Milošević, 2013). On the other hand, a small number are protected as cultural heritage and still are preserved, but they certainly do not have the same function and does not deliver the same message. Bearing in mind that generations born after 1991 have not been well-educated about the Yugoslav period, this situation is not surprising.

The vast damage was made to the monuments in the former republics, which were affected by the civil war because they were opposed to new national interests. In Bosnia and Hercegovina Partisan's memorials are deserted and forgotten, especially after the civil war (1992-1995). During the war, many monuments in this former republic were damaged or destroyed, such as Sanski Most, Makljen, Vraca, etc. In Croatia after independents, the commemorative practice was abandoned, and the conservation policy was changed. Yugoslav memorials have been destroyed, vandalized, and left to decay because they remind of the period that could not be well incorporated in the Croats new national narrative. They are perceived as the symbols of Serbian dominance and state union that Croats have never wanted (Begić and Mraović, 2014). In Croatia, the destruction of the monuments lasted from 1991 to 2000s, but the major damages happened during the war. During this period 2.964 memorials from the Yugoslav era were destroyed, damaged (e.g. stars removed or inscription change) or relocated (Hrženjak, 2002).

In Slovenia, Serbia and Macedonia symbols of Partisan struggle and liberation were more integrated into new national narratives, because other liberation groups got their memorials too, so the monuments from the Yugoslav past were not destroyed (Kirn and Burghardt, 2012). In Serbia, the NOB monuments were not demolished, but many of them were relocated from the main public locations to museums or some less attractive positions. For example, in 1997 monument dedicated to Boris Kidrič was relocated from Knez Miloš Street to 
plateau in front of the Museum of Contemporary Art in Belgrade. Furthermore, Tito's busts were removed from schools and public places. Besides, some of the monuments were vandalized by graffiti and other inscriptions. On the other hand, generally observed Serbia is a country that preserved a huge number of monuments from the Yugoslav period. Most memorials are at the same place where they were erected. Although there was no organized demolition or removal of the monuments, they have been forgotten, neglected, and left to decay.

\section{THE MODERN ATTEMPTS OF SOCIALIST MEMORIALS REVIVAL}

There were several modern attempts of socialist memorials revival. The so-called "UFO architecture" was presented to the international audience by the series of photographs titled "Spomenik" (Monuments) made by Belgian artist Jan Kempenaers during the 2006-2009 period. The exhibitions were organized in Belgium (2007), the Netherlands (2010), and the USA (2015). These mysterious monuments attracted international attention because of its megalomaniac size, abstract narratives, and materials (concrete, steel, granite), which is unusual for the European monuments of that epoch (Kempenaers, 2018). Another project was conducted by German artist Marc Schneider and presented at the exhibition "Ovde je metak ludovao" in the Street gallery in Belgrade during 2016. The exhibition showed monuments in different conditions of preservation from different parts of the former Yugoslavia (Schneider, 2017).

At the beginning of the XXI century in some former republics emerged "yugonostalgia". This resulted in several projects conducted in Serbia, in cooperation with the institutions from former state republics. The main aim was raising awareness about the importance of conservation and restoration of socialist memorials from the common past. The project "Unfinished Modernizations: Between Utopia and Pragmatism" (2012-2013) resulted in an exhibition held in all capitals of the former republics and publishing a monograph (Putnik, 2016). The recent international project "Inappropriate Monuments" was conceived to change the attitudes of the ex-Yugoslav audience towards NOB monuments. The idea was to create a joint interstate register of memorials and to find the best strategies for the management, maintenance, and protection. One of the project's outputs was the touring exhibition about the memorial tourism in Yugoslavia titled 'On Revolution Roads' (2015-2016). The authors strived to present the importance of memorial tourism in the former country. They recommended four tourist routes in former Yugoslavia connecting continental and coastal parts, with emphasize on the educational role of the NOB memorials (Bezel Theme, 2018). In 2012 the authors of the blog "Yugodrom" launched the postcard series "Yu pozdravi" dedicated to NOB memorials and their touristic value, as a way to draw attention to the value of the monuments and need for their conservation and restoration (Savić and Cvetković, 2018).

\section{IS THERE ANY PLACE FOR YUGOSLAV MEMORIALS IN THE CURRENT SERBIAN TOURIST OFFER?}

After the fall of Yugoslavia and the abandonment of the idea of "brotherhood and unity", the memorials that celebrated Partisan struggle were mostly neglected and left out of the official tourist offer. These memorials are well-known only among the generations that lived in former Yugoslavia. It is practically unknown to the youth due to school curricula revision and the exclusion of memorials from the educational programs.

Despite their artistic, historic, and educational value, the memorials from the Yugoslav period were omitted from the official tourist offer of Serbia. It becomes certain when we observe the accommodation capacities near the memorial complexes, they are empty (Musa et al., 2015). The one is sure - memorials are not neglected due to their faded beauty and value, but due to new political circumstances.

In Serbia, only seven memorials from the Yugoslav period are protected as cultural heritage of extraordinary or high importance, but not even they are properly maintained (Table 1). Observing their inclusion in tourism offer, it can be concluded that six of these most prominent are only mentioned in the list of recommended attractions by relevant tourism organizations (Memorial Complex Boško Buha is excluded). Only Memorial Park October in Kragujevac and Memorial Park Slobodište are included in programs of sightseeing tours. Among Serbian memorials from WWII, Memorial Park October in Kragujevac is most visible for potential tourists, thanks to activities of Museum 21st October, which is a part of complex (permanent 
exhibition, guided multi-language tours, literary-visual arts competition One Šumarice is enough to the world, the traditional music manifestation The Pilgrimage of October - OKTON, Anti-war cartoon salon, Bridges of Balkan, etc.) (Memorial park October in Kragujevac, 2016). About other memorials, potential tourist can be informed through the Internet or social media and to organize tours by themselves.

Table 1. The protected WWII memorials in Serbia

\begin{tabular}{lccccc}
\hline \multicolumn{1}{c}{ Memorial } & Location & Purpose & Year & Protection & Type of visits \\
\hline $\begin{array}{l}\text { Memorial Park October in } \\
\text { Kragujevac }\end{array}$ & Kragujevac & $\begin{array}{c}\text { Kragujevac masacre in } \\
1941\end{array}$ & 1953 & $1979^{\mathrm{a}}$ & $\begin{array}{c}\text { Annual events, } \\
\text { excursions }\end{array}$ \\
\hline $\begin{array}{l}\text { Memorial Complex Bela Crkva } \\
\text { Memorial Park Slobodište }\end{array}$ & Krupanj & Uprising 7 $7^{\text {th }}$ July 1941 & $1951-71$ & $1979^{\mathrm{a}}$ & Individual \\
\hline Kemorial Complex Boško Buha & Jabuka & Kruševac masacre in 1943 & $1965-78$ & $1983^{\mathrm{b}}$ & Individual \\
\hline Memorial Park Bubanj & Niš & Execution in Niš & $1950-63$ & $1979^{\mathrm{a}}$ & Individual \\
\hline Partisan Hospital & Prijepolje & Prijepolje battle in 1943 & $1941-53$ & $1979^{\mathrm{a}}$ & Individual \\
\hline Memorial Complex Kadinjača & Užice & Kadinjača battle in 1941 & $1978-79$ & $1979^{\mathrm{a}}$ & Individual \\
\hline
\end{tabular}

Source: National Center for Digitization (2018); Republički zavod za zaštitu spomenika kulture Beograd (2018)

${ }^{a}$ cultural heritage of extraordinary importance

${ }^{\mathrm{b}}$ cultural heritage of high importance

${ }^{\star}$ National Liberation Struggle

On the other hand, the heritage from the Yugoslav period has high tourism potential, which could be valorized through cultural tourism and its subforms. The most important precondition for treating socialist memorials as tourist attractions is accepting socialist memorials as the heritage of all ex-Yugoslav republics and to implement necessary revitalization and conservation programs (Putnik, 2016). Observing global tendencies in tourism demand, socialist's heritage could be valorized through selective forms of tourism - memorial, nostalgia, educational, dark tourism, but also through the concept of forming cultural routes.

Dark tourism attracts growing attention from all over the world. This form of tourism includes visiting places connecting with the human suffering, macabre, and atrocities. With heritage from the different epochs, Serbia has already been recognized as a dark tourism destination. Among the globally recognized Serbian dark attraction are some memorials from Yugoslav era: Concentration camp Red Cross (Niš), Military Museum, Tito mausoleum \& museum, Museum of Banjica concentration camp, and Sajmiste concentration camp (all in Belgrade) (Hohenhaus, 2018). Tourism policymakers should use growing international attention and promote memorials in the other parts of the country as dark tourism attractions.

Furthermore, the approach of creating the cultural routes seems very acceptable, considering the number of memorials in Serbia and other former republics. The cultural route is a road that connects several countries or regions that share the same historic, artistic or social background and always includes a series of tourist attractions (ICOMOS, 2008). The concept of cultural routes represents the big opportunity for the underdeveloped regions with tourist resources because the potential tourists are encouraged to travel between sites along the route (Terzić et al., 2014). Applying this concept would allow cooperation with other former republics and gaining multiple benefits for both the relevant institutions and the local community.

Besides, as Putnik (2016) suggested, there should be different strategies in the approaching domestic and foreign tourists. The international audience became familiar with the aesthetic value of the socialist memorials through the above-mentioned exhibitions and monographs, but they do not know the real purpose and their memorial value. The tourist products intended for foreign tourists should emphasize the historic and educative functions of the memorials. The foreigners should be able to emotionally experience the value of the "alien landmark" or "UFO architecture". On the other hand, within the local people memories from the previous period are still vivid. They have mostly visited these memorials during the school excursions with 
dominant educative function. Because of that, they do not see the aesthetic value of the monuments. Especially, the bad experiences are strong among the opponents of the previous regime, so in the tourist promotion, the artistic value should be highlighted. Besides, the integral part of the tourist offer should be tours intended for the younger generation that will combine educative, historic, and artistic concepts, which will allow them to obtain a complete picture of memorials.

\section{CONCLUSIONS}

The memorial presented to the global audience through touring exhibitions, online portals and blogs resulted in tourist potential that policymakers have not recognized. The main reason is certainly a common attitude towards memorials and Yugoslav past. After the collapse of state union heritage from the Yugoslav period became a dissonant heritage. Whether we support the idea of Yugoslavia, memorials are part of our common history and it cannot be denied. These artistic achievements give us the opportunity to learn about the history that was created for almost 50 years. The Yugoslav memorials erected in the "golden age" (1960-1980) do not represent idealized Partisan figures or socialist symbols (red star, sickle, and hammer). They have the abstract forms that do not have to be interpreted only through socialist ideas. These abstract forms convey the message of catharsis memory or memory of forgiveness that is universal and timeless (Putnik, 2014; Djurić, 2015).

Including the memorials in the official tourism offer of Serbia in forms of dark, educational or cultural tours would attract more cultural tourist, who are well-educated, richer and spend more money on vacations. Besides, creating cultural routes that connect many socialists' monuments would help to revive local economies, whose tourist facilities are empty nowadays. On the other side, the best results would be achieved by launching regional projects and cultural routes, which connect memorials from all former republics. In that way, the whole former Yugoslavia would have benefited from the unwanted past (Putnik, 2016).

\section{ACKNOWLEDGMENT}

The study is a result of the Project 47007 III funded by Ministry of Education, Science and Technological Development of the Republic of Serbia.

\section{REFERENCES}

Begić S. \& Mraović B. (2014). Forsaken Monuments and Social Change: The Function of Socialist Monuments in the Post-Yugoslav Space. In: S. Moeschberger \& R. Phillips DeZalia (Eds.), Symbols that Bind, Symbols that Divide. Peace Psychology Book Series (pp. 13-37). Cham: Springer. DOI:10.1007/978-3-319-05464-3_2

Bezel Theme. (2018). Inappropriate monuments. Retrieved August 17, 2018, from https://inappropriatemonuments.org/hr.

Craine, K. (1999). Incorporating Cultural Tourism into National Tourism Week Activities. Washington: Tourism Industry Association of America.

Dizdarević, L. \& Hudović, A. (2012). The lost ideology - Socialist Monuments in Bosnia. In 1st International Conference on Architecture \& Urban Design Proceedings, 19-21 April 2012 (pp. 455-464). Tirana, Albania: EPOKA University.

Djurić, I. (2015). Memorials without memory (Doctoral dissertation, Prima Universita di Roma Sapienza). Retrieved August 18, 2018, from: https://web.uniroma1.it/dottcomparch/sites/default/files/27Djuric.pdf.

Dragićević Šešić, M. (2011). Cultural policies, identities and monument building in Southeastern Europe. In A. Milohnić \& N. Švob-Đokić. (Eds.), Cultural Transitions in Southeastern Europe. Cultural Identity Politics in the (Post-) Transitional Societies (pp 31-46). Zagreb: Institute for International Relations.

ICOMOS. (2008). The ICOMOS Charter for the Interpretation and Presentation of Cultural Heritage Sites. Retrieved August 15, 2008, from https://www.icomos.org/charters/interpretation_e.pdf.

Jauković, M. (2015). To Share or to Keep: The Afterlife of Yugoslavia's Heritage and the Contemporary Heritage Management Practices. Croatian Political Science Review, 51(5), pp. 80-104. Retrieved August 15, 2018, from: https://hrcak.srce.hr/138559. 
Jovičić, D. (2008). Uvod u turizmologiju i turističku geografiju. Novi Beograd: Ton PLUS (in Serbian).

Kemmerling Clack, J. (1999). Cultural tourism: an overview of impact, visitors and case studies. In Navigating global water - 30th annual conference proceedings (pp. 154-159). Boise ID: Travel and Tourism Research Association.

Kempenaers, J. (2018). Works and Exhibitions. Retrieved September 1, 2018, from http://www.jankempenaers. info.

Kerstetter, D., Confer, J., \& Bricker, K. (1998). Industrial heritage attractions: Types and tourists. Journal of Travel and Tourism Marketing, 7(2), 91-104. DOI:10.1300/J073v07n02_05.

Kirn, G. \& Burghardt, R. (2012). Yugoslavian Partisan Memorials: the aesthetic form of the revolution as a form of unfinished modernism? In M. Mrduljaš \& V. Kulid (Eds.), Unfinished Modernization: between utopia and pragmatism (pp. 84-95). Zagreb: Croatian Architects' Association.

Hohenhaus, P. (2010-2018). Serbia. Retrieved August 15, 2018, from http://www.dark-tourism.com/index.php/ serbia.

Hrženjak, J. (2002). Rušenje antifašističkih spomenika u Hrvatskoj 1990-2000. Zagreb: Savez antifašističkih boraca Hrvatske (in Croatian).

McKercher, B. (2002). Towards a classification of cultural tourists. International Journal of Tourism Research, 4(1), pp. 29-38. DOI:10.1002/jtr.346.

McKercher, B. \& du Cros, H. (2003). Testing a Cultural Tourism Typology. International Journal of Tourism Research, 5(1), pp. 45-58. DOI: 10.1002/jtr.417

Milošević, S. (2013). Seeking Identity in Former Yugoslavia's Socialist Architecture (Master Dissertation, University of Cincinnati). Retrieved August 15, 2018, from: https://etd.ohiolink.edu/pg_10?0::NO:10:P10_ACCESSION_NUM:ucin1378196389\#abstract-files.

Memorial park October in Kragujevac (2016). The history. Retrieved September 1, 2018, from https://www. spomenpark.rs.

Musa, S., Kranjčević, J. \& Šakić, D. (2015). Do Memorial Sites from the Second World War Possess Potential for Tourism Development - Examples from Croatia and Bosnia and Herzegovina. In the Book of Abstract, International Tourism and Hospitality Management Conference, 30. September - 04. October 2015. (pp. 31). Sarajevo: Faculty of Science, University of Sarajevo.

National Center for Digitization. (2005). Cultural Monuments in Serbia. Retrieved August 21, 2018, from http:// spomenicikulture.mi.sanu.ac.rs.

OECD. (2009). The Impact of Culture on Tourism. Paris. Retrieved August 15, 2018, from http://fasos.maastrichtuniversity.nl/profiles/Evans/OECD_Tourism_Culture.pdf.

Prekić, A. (2015). Tradicija NOB-a u crnogorskom društvu. Matica crnogorska, 64, pp. 279-312. http://www. maticacrnogorska.me/files/64/13\%20adnan\%20prekic.pdf (in Serbian).

Putnik, V. (2014). Memorijalna skulptura Miodraga Živkovića (period 1960-1980). In N. Zivkovic (Ed.), Javni spomenici i spomen obeležja: kolektivno pamćenje i/ili zaborav (pp. 116-124). Beograd: Zavod za zaštitu spomenika kulture grada (in Serbian).

Putnik, V. (2016). Second World War monuments in Yugoslavia as witnesses of the past and the future. Journal of Tourism and Cultural Change, 55(1), 206-221. DOI:10.2478/s11600-006-0043-6.

Republički zavod za zaštitu spomenika kulture Beograd. (2018). Nepokretna kulturna dobra. Retrieved September 9, 2018, from http://www.heritage.gov.rs/latinica/nepokretna_kulturna_dobra.php (in Serbian).

Savić, M. \& Cvetković, V. (2018). Yu pozdravi. Retrieved September 1, 2018, from http://yugodrom.com/yupozdravi.html (in Serbian).

Savković, M. (2018). Ka betonskoj utopiji: Šta je MoMA naučila od Jugoslavije. Retrieved September 6, 2018, from https://kljucaonica.com/2018/05/28/ka-betonskoj-utopiji (in Serbian).

Schneider, M. (2017). Krojačblog. Retrieved September 1, 2018, from http://markokrojac.blogspot.com.

Terzić, A., Bjeljac, Ž., \& Jovanović, R. (2014). Zaštita, revitalizacija i upotreba nasleđa kroz sistem formiranja kulturnih ruta: Evaluacija master plana Put rimskih careva. Kultura, 143, 319-335. DOI:10.5937/kultura1443319t (in Serbian).

Timothy, D. J. (1997). Tourism and the personal heritage experience. Annals of Tourism Research, 24(3), 751754. DOI: 10.1016/S0160-7383(97)00006-6.

Vajagić, P. (2017). Kultura sećanja - Sremski front. Vojno delo, 3, 415-434. DOI:10.5937/vojdelo1703415V (in Serbian). 